\title{
Coarse Woody Debris' Invertebrate Community is Affected Directly by Canopy Type and Indirectly by Thinning in Mixed Scots Pine-European Beech Forests
}

\author{
Ximena Herrera-Alvarez ${ }^{1,2}$, Juan A. Blanco ${ }^{1, * \mathbb{C}}$, J. Bosco Imbert ${ }^{1}$, Willin Alvarez ${ }^{2}$ and \\ Gabriela Rivadeneira-Barba ${ }^{3}$ \\ 1 Departamento de Ciencias, Institute for Multidisciplinary Research in Applied Biology-IMAB, \\ Universidad Pública de Navarra, Campus de Arrosadía, Pamplona, 31006 Navarra, Spain; \\ ximena.herrera@unavarra.es (X.H.-A.); bosco.imbert@unavarra.es (J.B.I.) \\ 2 Universidad Regional Amazónica Ikiam, 150102 Tena, Ecuador; willin.alvarez@ikiam.edu.ec \\ 3 Laboratorio de Entomología, Escuela de Ciencias Biológicas, Pontificia Universidad Católica del Ecuador, \\ 17012184 Quito, Ecuador; gabrielarb91@gmail.com \\ * Correspondence: juan.blanco@unavarra.es; Tel.: +34-948-169-859
}

Received: 13 August 2020; Accepted: 7 September 2020; Published: 9 September 2020

\begin{abstract}
Research Highlights: Thinning and tree species alter the forest floor microclimate by modifying canopy cover, radiation, wind, and humidity. Thus, forest management can directly influence the edaphic mesofauna responsible for decomposing coarse woody debris (CWD). Background and Objectives: This research was carried out in the Southwestern Pyrenees Mountains (Northern Spain) and aimed to determine the influence of forest thinning and canopy type (pure Pinus sylvestris $\mathrm{L}$. or a mix of P. sylvestris and Fagus sylvatica L.) on CWD colonization by edaphic fauna. Materials and Methods: CWD samples were collected belonging to intermediate and advanced decomposition stages, approximately $10 \mathrm{~cm}$ long and $5 \mathrm{~cm}$ in diameter. Using a design of three thinning intensities $(0 \%, 20 \%$, and $40 \%$ of basal area removed), with three replications per treatment (nine plots in total), four samples were taken per plot (two per canopy type) to reach 36 samples in total. Meso- and macrofauna were extracted from CWD samples with Berlese-Tullgren funnels, and individuals were counted and identified. Results: 19 taxonomic groups were recorded, the most abundant being the mesofauna (mites and Collembola). Mixed canopy type had a significant positive influence on richness, whereas advanced decay class had a positive significant influence on total abundance and richness. In addition, there were non-significant decreasing trends in richness and abundance with increasing thinning intensity. However, interactions among thinning intensity, canopy type, and decay class significantly affected mesofauna. Furthermore, some taxonomic groups showed differential responses to canopy type. CWD water content was positively correlated with total invertebrate abundance and some taxonomic groups. Our results suggest that stand composition has the potential to directly affect invertebrate communities in CWD, whereas stand density influence is indirect and mostly realized through changes in CWD moisture. As mesofauna is related to CWD decomposition rates, these effects should be accounted for when planning forest management transition from pure to mixed forests.
\end{abstract}

Keywords: Pinus sylvestris; Fagus sylvatica; forest thinning; species composition; mesofauna; invertebrates

\section{Introduction}

Coarse woody debris (CWD) are very important for forest ecosystems due to their multiple ecological functions, such as regulating carbon and nutrient cycles and providing different structural 
properties to forest soils, such as affecting sediment transport storage and water retention [1,2]. Previous works have also emphasized the importance of CWD for species diversity conservation. For example, brown bears (Ursus arctos L.) feed on carpenter ants (Camponotus herculeanus L.) that inhabit CWD [3]. Similarly, mean species richness and diversity of small mammals reach their highest values in CWD from windthrow sites [4]. In addition, the removal of biomass from CWD and standing dead trees decreases bird diversity and can even alter prey-predator relationships with insects and other taxonomic groups [5]. Additionally, CWD increase soil microbial activity and fertility, depending on the decomposition of the wood that releases nutrients such as nitrogen and phosphorus. However, to facilitate the release of nutrients from the fallen woody remains, it is necessary that such substrate is colonized by several taxonomic groups of invertebrates which, accompanied by microorganisms and abiotic factors, promote their total decomposition [6].

CWD are usually divided into five different decay classes from fresh (class 1) to fully decomposed (class 5) [7]. Chronologically, freshly woody debris are colonized by fungi and xylophagous insects that disperse these fungi [6], followed by Diptera larvae, mites, and centipedes and coleopteran predators [8]. Consequently, greater abundances of xylophages and their predators are found in the initial decomposition classes. As decomposition proceeds, social insects such as ants or termites excavate their nests [1], feeding on fungi and broken sapwood. Hence, saprophages and parasitoids are more abundant in intermediate stages [2,9]. In the most advanced stages, fungi, organisms that feed on rotten wood and their predators become dominant $[8,10,11]$.

CWD production rates can be influenced by forest management practices [9,12]. Forest thinning is commonly used to control stand density and productivity [13], and to manage competition and nutrient cycling in forests, which is particularly important in mixed forests [14,15]. In addition, forest management practices in Europe are undergoing a paradigm change, transitioning from pure to mixed forests due to their higher productivity and resilience against disturbances $[15,16]$. However, little is known on the effects of management on mesofauna communities in forest floor [17] and even less in CWD [9].

Previous research, conducted by our team in mixed forests of Scots pine (Pinus sylvestris L.) and European beech (Fagus sylvatica L.) in the Southwestern Pyrenees, has found that forest thinning reduces litter biomass and nutrient reserves, alters litter production and decomposition rates [18-21], decreases the volume and biomass of fallen woody debris [21,22], and changes the microclimate [14]. In addition, water content of coarse woody debris is usually one of the main environmental factors that could contribute to the invertebrate community response. In particular, in Mediterranean forests characterized by summer drought, moisture is a main factor affecting CWD decomposition rates [23], and it is directly related to mesofaunal activity. However, most research on CWD decomposition in managed forests has been focused on microbial decomposition (particularly fungi [2,9]), while little is known on how forest management alters the invertebrate community.

Change in microclimate due to forest thinning could also influence flora and wildlife species composition. In this context, it is known that forest thinning also reduces bird diversity, bat activity, flying insects' biomass such as Lepidoptera (moths), dipterans, and other arthropods [24]. In addition, some taxonomic groups such as spiders have been previously identified as potential bioindicators of forest thinning [25]. For example, [26] identified an increase in functional diversity of spiders after thinning in Central European forests, whereas [27] reported the highest spider diversity in stands of medium canopy openness. In spite of that, the influence of forest thinning on invertebrates living in the leaf litter, CWD, or soil is poorly studied. Likewise, invertebrates can be affected not only by forest thinning. Other factors such as dominant tree species and their canopy coverage influence the activity, species richness, and abundance of some taxonomic groups such as Opiliones, Carabidae, or some Collembola families [28].

Based on this background, it is reasonable to think that, if in the forests object of this study (temperate mixed Scots pine and European beech forests) litter invertebrates have been affected by forest management and canopy type [29], woody debris colonization by invertebrates may have also 
been altered. Therefore, our first initial hypothesis is that, similarly to invertebrates in litter [20], the reduction of stand density could have favored a greater desiccation and insolation of the woody debris, reducing or slowing down their colonization by invertebrates. In addition, we also hypothesize that tree canopy type (pure pine or mixed pine and beech) can affect this process by generating a different microclimate in the forest floor due to the greater shading existing under the mixed canopy [14,30].

To test such hypotheses, the main objective of this research was to study the colonization process by mesofauna in CWD after applying different thinning intensities, as well as to determine whether the type of canopy and the decomposition class of CWD could influence the abundance, richness, and diversity of invertebrate present. In this context, it is expected that certain abiotic variables such as water content of woody debris and type of canopy cover under different intensities of thinning can explain the results found.

\section{Materials and Methods}

\subsection{Study Area}

This research was carried out in a mixed natural forest in the Southwestern Pyrenees (Navarre Province, Northern Spain), being the dominant tree species Scots pine and as codominant species European beech. These two species are the most important for European silviculture, and they share their distribution zones in large regions (Figure 1). In the Pyrenees Mountains, Scots pine and European beech have expanded its distribution after the abandonment of marginal agricultural lands since the 1960s. European beech has also recolonized areas where it was previously suppressed by forest thinning to reduce its competition with pine. Which species benefits the most in mixed canopies depends on complex interactions between the availability of resources, water, and nutrients [31].
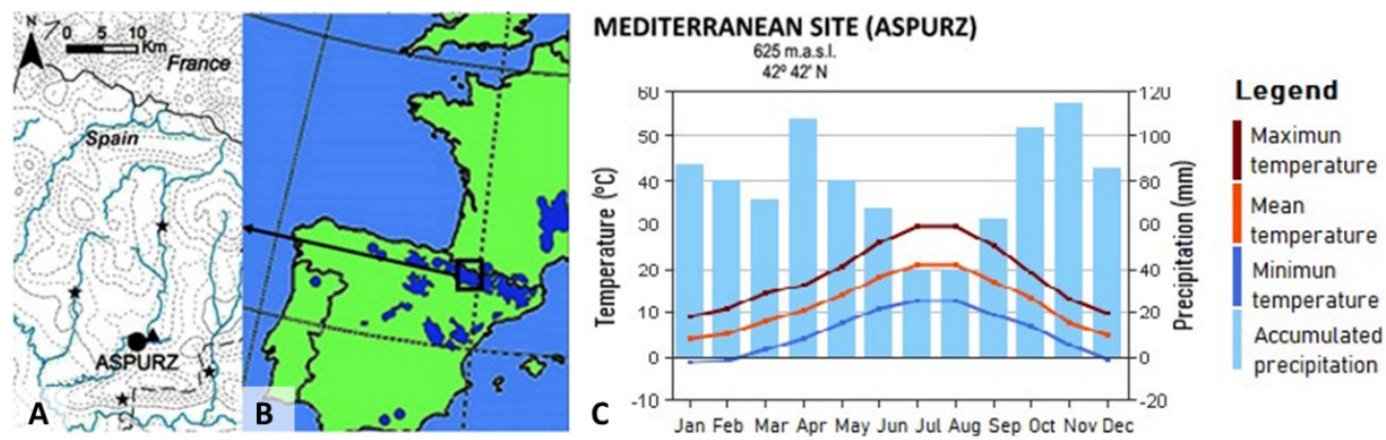

Figure 1. (A) Location of the experimental plots (circle) and the weather station (Navascués) providing historical climate (triangle), and the one used to fill weather records gaps (stars). (B) Location of the area in the Iberian Peninsula within the distribution of Scots pine in the region [32]. (C) Climatic diagrams for the study site for the period 1984-2019 [33].

The research site is located near the town of Aspurz, the forest being a moist Mediterranean montane type (Table 1). In this stand, Scots pine regenerated naturally after the previous stand was harvested in strips some 60 years ago. In 1999, the Forest Service of the Government of Navarre established a forest thinning trial that provided the first data for a long-term monitoring program with the Ecology and Environment Group of the Public University of Navarre. A detailed description of the area can be found in $[34,35]$.

\subsection{Experimental Design}

The experimental design consisted of nine $40 \times 30 \mathrm{~m}$ plots. Three treatments were replicated three times: control ( $0 \%$ of basal area removed); intermediate thinning $(20 \%$ of the Scots pine basal area eliminated in 1999 and again in 2009), and intense thinning (30\% of the Scots pine basal area was removed in 1999 and 40\% in 2009). In 1999, the stumps were left on the ground and most of the trunks 
and cut branches were removed [37]. In 2009, the stumps were left on site but the trunks and large branches were removed for commercial use, leaving the rest of the harvested material in the plots. The trees harvested in 1999 were mainly sick, malformed or dead, whereas in 2009, harvested trees were mainly dominant and some codominant with malformed stems [14,20]. To avoid the edge effect, the same treatment was applied to a strip of 5-10 m adjacent to each thinned plot. Each plot was mapped into two sub-plots depending on the types of arboreal canopy: composed of pure pine crowns or composed of a mixture of pine and beech crowns (and other broadleaved species if present, Table 2). The mixed canopy was delimited by the projections on the ground of the crowns of beech trees taller than $2 \mathrm{~m}$.

Table 1. Characteristics of the study area common to both canopy types [34,35].

\begin{tabular}{cc}
\hline Variable & Value \\
\hline Forest type & Mediterranean-montane \\
Latitude & $42^{\circ} 42^{\prime} 31^{\prime \prime} \mathrm{N}$ \\
Length & $1^{\circ} 8^{\prime} 40^{\prime \prime} \mathrm{W}$ \\
Altitude (meters) & 625 \\
Slope $(\%)$ & 7 \\
Soil type & Haplic alisol \\
Mean Temperature $\left({ }^{\circ} \mathrm{C}\right)$ & 12.0 \\
Mean Temperature media May-October $\left({ }^{\circ} \mathrm{C}\right)$ & 16.8 \\
Annual Mean Precipitation $(\mathrm{mm})$ & 912 \\
Annual Mean Precipitation May-October $(\mathrm{mm})$ & 402 \\
Climate type [36] & Cold Mediterranean climate \\
Understory dominant species & Pteridium aquilinum (L.) Kuhn, Rubus ulmifolius Schott \\
\hline
\end{tabular}

\subsection{Samples Collection and Laboratory Work}

Thirty-six samples of pine woody debris were collected in late April 2015. The decay classes collected were class 3 and 4 according to the classification by [7]. These samples were divided according to the definition by [1] and were randomly collected under thinning treatments such as control, intermediate $(20 \%)$ and intense $(40 \%)$ thinning. Eighteen samples were collected under pure pine canopy, and 18 under mixed canopy of pine, beech and other deciduous, collecting one sample of each decay class in each sub-plot. Collected samples were approximately wood cylinders $10 \mathrm{~cm}$ long and 5 in diameter. In the laboratory, these samples were weighed (to $\pm 0.1 \mathrm{~g}$ ) as fresh weight and then placed in a Berlese-Tullgren funnel (a $40 \mathrm{~W}$ lightbulb on top of a sample container $15 \mathrm{~cm}$ length $\times 8 \mathrm{~cm}$ diameter with $2 \mathrm{~mm}$ nylon mesh at the bottom) for mesofauna extraction for six days, collecting the mesofauna in glass containers with $70 \%$ ethanol. After extracting the mesofauna, woody samples were dried for $72 \mathrm{~h}$ in an oven at $70{ }^{\circ} \mathrm{C}$ and weighed. Water content percentage of coarse woody debris was determined by the difference of fresh and dry weights.

The contents of each container were analyzed with a stereoscope, the invertebrates being identified with a key guidebook [41] and following a list of taxonomic groups of invertebrates previously found in leaf litter at the same plots by [29]. In this way, the invertebrates found were classified according to their order and some even suborder. Mesofauna groups recorded in this research (considered as the taxonomic groups with a body size $<2 \mathrm{~mm}$ [42]), were oribatid mites, other mites, immature mites, Collembola, and Nematoda. The classification by [42] is not tight in size limits as several species and development stages of orders belonging to the macrofauna can have body sizes smaller than $2 \mathrm{~mm}$. Therefore, although the mesh size may have clearly limited the extraction of macrofauna, several taxonomic groups were collected. The taxonomic groups of macrofauna (body size $>2 \mathrm{~mm}$ [42]) were immature stages of macrofauna (larvae), Diptera, Geophilomorpha, Hymenoptera, Oligochaeta, Symphyla, Thysanoptera, Araneae, Pseudoscorpionidae, Lithobiomorpha, Pauropoda, Chilopoda, and Hemiptera. Total abundance of each taxonomic group was divided by sample weight. 
Table 2. Environmental variables in each thinning intensity and canopy type.

\begin{tabular}{|c|c|c|c|c|c|c|c|}
\hline \multirow{2}{*}{$\begin{array}{c}\text { Variable } \\
\text { Thinning Intensity } \\
\text { (Pine Basal Area Removed) }\end{array}$} & \multicolumn{6}{|c|}{ Canopy Type } & \multirow[t]{2}{*}{ Source } \\
\hline & \multicolumn{2}{|c|}{$0 \%$} & \multicolumn{2}{|c|}{$20 \%$} & \multicolumn{2}{|c|}{$40 \%$} & \\
\hline Pine density (stems ha ${ }^{-1}$ ) & \multicolumn{2}{|c|}{$1456 \pm 156$} & \multicolumn{2}{|c|}{$1125 \pm 83$} & \multicolumn{2}{|c|}{$1078 \pm 147$} & {$[31,38]$} \\
\hline Beech density (stems ha ${ }^{-1}$ ) & \multicolumn{2}{|c|}{$246 \pm 26$} & \multicolumn{2}{|c|}{$190 \pm 14$} & \multicolumn{2}{|c|}{$182 \pm 25$} & {$[31,38]$} \\
\hline Other deciduous density (stems ha ${ }^{-1}$ ) & \multicolumn{2}{|c|}{$399+43$} & \multicolumn{2}{|c|}{$308 \pm 23$} & \multicolumn{2}{|c|}{$296 \pm 40$} & {$[31,38]$} \\
\hline Pine basal area $\left(\mathrm{m}^{2} \mathrm{ha}^{-1}\right)$ & \multicolumn{2}{|c|}{$40.9 \pm 1.4$} & \multicolumn{2}{|c|}{$35.0 \pm 2.4$} & \multicolumn{2}{|c|}{$30.4 \pm 1.5$} & [38] \\
\hline Canopy Type & Pine & Mixed & Pine & Mixed & Pine & Mixed & \\
\hline Leaf Area Index $\left(\mathrm{m} \mathrm{m}^{-1}\right)$ & $2.65 \pm 0.12$ & $2.86 \pm 0.20$ & $2.69 \pm 0.10$ & $2.68 \pm 0.25$ & $2.59 \pm 0.16$ & $2.62 \pm 0.13$ & [39] \\
\hline Ground cover $(\%)$ & $0.67 \pm 0.05$ & $0.80 \pm 0.04$ & $0.60 \pm 0.04$ & $0.76 \pm 0.06$ & $0.55 \pm 0.07$ & $0.74 \pm 0.06$ & [39] \\
\hline Canopy openness (\%) & $0.11 \pm 0.01$ & $0.08 \pm 0.01$ & $0.12 \pm 0.01$ & $0.10 \pm 0.01$ & $0.12 \pm 0.01$ & $0.09 \pm 0.01$ & [39] \\
\hline Annual throughfall (mm) & $898 \pm 56$ & $653 \pm 43$ & $904 \pm 55$ & $846 \pm 50$ & $918 \pm 56$ & $790 \pm 42$ & [40] \\
\hline
\end{tabular}




\subsection{Data Analysis}

We estimated richness and the Shannon-Wiener diversity index per sample. The effects of thinning, canopy type and CWD decay class on total abundance of macro and mesofauna, species richness, Shannon-Wiener index, and CWD water content were analyzed using the nonparametric Kruskal-Wallis test, as data did not follow a normal distribution. Generalized mixed models (GLM) with Poisson distribution were used to analyze the interactions between thinning intensity, canopy type, and CWD decay class for the variables of water content of CWD and total abundance of invertebrates per gram of decayed wood. Principal component analyses (PCA) were performed considering the variables that represented the variance in a greater percentage, being such variables: CWD water content, total abundance per gram of oribatid mites, other mites, Collembola, immature stages of macrofauna (larvae), immature mites, Coleoptera, and total abundance. The software used in this research was R Studio version 3.1.3. (RStudio, Boston, MA, USA, 2020) and IBM SPSS Statistics version 25 (IBM Corporation, Armonk, NY, USA, 2017).

\section{Results}

\subsection{Invertebrate Community Composition}

We registered a total of 8348 individuals belonging to 19 taxonomic groups in all different treatments combined (Table 3). The largest number of individuals (accounting for $96.75 \%$ ) belonged to the mesofauna, being dominated by the Acariform order with $80.07 \%$, subdivided into oribatid mites $(19.11 \%)$, other mites $(14.52 \%)$, and immature mites $(46.44 \%)$ (Table 3$)$. The Collembola order was also one of the most abundant taxonomic groups with a percentage of $16.67 \%$. Nematodes had the lowest total abundance $(0.01 \%)$ within the mesofauna. The macrofauna only represented $3.28 \%$ of the total number of individuals, subdivided into the classes Insecta $(1.09 \%)$, Arachnida $(0.19 \%)$, Chilopoda $(0.19 \%)$, Pauropoda $(0.07 \%)$, Oligochaeta $(0.04 \%)$, Symphyla $(0.24 \%)$, and larvae (immature stages of macrofauna) $(1.43 \%)$ (Table 3$)$.

\subsection{Thinning Influence on Invertebrate Community}

Sixteen, 14, and 12 taxonomic groups were found in treatments with thinning intensities of $0 \%$, $20 \%$, and $40 \%$, respectively (Table 4). Significant differences between thinning intensities were found only for Thysanoptera $\left(X_{d f 2}^{2}=6.325, p=0.042\right)$. However, a tendency to greater absolute abundance of macrofauna and mesofauna was observed in control plots compared to thinned plots for these taxa: other mites, immature mites, Collembola, Geophilomorpha, Hymenoptera, Oligochaeta, Symphyla, Thysanoptera, Lithobiomorpha, Pauropoda, and Unidentified Chilopoda. In addition, Oligochaeta, Thysanoptera, and Pauropoda were only found in control plots (Table 4).

Higher absolute abundance was found under $20 \%$ thinning intensity than under other thinning intensities for oribatid and immature stages of macrofauna (larvae). In addition, Pseudoscorpionidae and Nematoda were only found in $20 \%$ thinning intensity (Table 4). The taxa Araneae and Coleoptera were found with a higher abundance in the plots of $40 \%$ thinning intensity than other thinning intensities plots, while the order Hemiptera was only registered in $20 \%$ thinned plots (Table 4 ). Total abundance and species richness decreased with thinning intensity although no significant differences were found between treatments. No clear patterns for the Shannon-Wiener index were found (Table 5). Interestingly, in spite of not detecting direct significant effects of thinning, GLM results indicated a significant interaction between thinning intensity and decay class $\left(D_{d f 2}=3.557, p=0.050\right)$, for which CWD in heavily thinned plots had the lowest invertebrate abundance.

Although no significant differences were found between thinning intensities for CWD water content using the Kruskal-Wallis test, a clear tendency to higher water content in control and $20 \%$ plots in comparison to the $40 \%$ plots was found, with a relative reduction of $20.2 \%$ in CWD humidity in the latter (Table 5). 
Table 3. Total number of individuals of the taxonomic groups identified in decomposing woody debris, the taxa are classified by size (mesofauna and macrofauna). Cl.: class, $\mathrm{Sb}$. Cl.: sub-class; O.: order; Fil.: Filum. Bold case indicates the highest taxonomic orders (meso- and macrofauna, Class or Filum).

\begin{tabular}{|c|c|c|}
\hline $\begin{array}{l}\text { Taxonomic Group } \\
\text { All samples }\end{array}$ & $\begin{array}{c}\mathbf{N}^{\circ} \text { of Individuals } \\
8348\end{array}$ & $\begin{array}{c}\text { Fraction }(\%) \\
100\end{array}$ \\
\hline Mesofauna & 8077 & 96.75 \\
\hline Cl. Arachnida & 6684 & 80.07 \\
\hline \multicolumn{3}{|l|}{ Sb. cl. Acarina } \\
\hline Super O. Acariforme & 6684 & 80.07 \\
\hline O. Oribatid & 1595 & 19.11 \\
\hline Other mites & 1212 & 14.52 \\
\hline Immature mites & 3877 & 46.44 \\
\hline Cl. Entognatha & 1392 & 16.67 \\
\hline \multicolumn{3}{|l|}{ Sb. cl. Collembola } \\
\hline O. Collembola & 1392 & 16.67 \\
\hline Fil. Nematoda & 1 & 0.01 \\
\hline Macrofauna & 271 & 3.25 \\
\hline Cl. Insecta & 91 & 1.09 \\
\hline \multicolumn{3}{|l|}{ Sb. cl. Pterygota } \\
\hline O. Diptera & 17 & 0.17 \\
\hline O. Thysanoptera & 4 & 0.05 \\
\hline O. Coleoptera & 44 & 0.53 \\
\hline O. Hymenoptera & 25 & 0.3 \\
\hline O. Hemiptera & 1 & 0.01 \\
\hline Cl. Arachnida & 16 & 0.19 \\
\hline O. Pseudoscorpionida & 1 & 0.01 \\
\hline O. Araneae & 15 & 0.18 \\
\hline Cl. Chilopoda & 16 & 0.19 \\
\hline O. Geophilomorpha & 9 & 0.11 \\
\hline O. Lithobiomorpha & 9 & 0.11 \\
\hline Unidentified Chilopoda & 3 & 0.04 \\
\hline Cl. Pauropoda & 6 & 0.07 \\
\hline Cl. Clitellata & 3 & 0.04 \\
\hline Sb. cl. Oligochaeta & 3 & 0.04 \\
\hline Cl. Symphyla & 20 & 0.24 \\
\hline $\begin{array}{l}\text { Immature macrofauna stages } \\
\text { (larvae) }\end{array}$ & 119 & 1.43 \\
\hline
\end{tabular}


Table 4. Mean abundances \pm SE per gram of sample of each taxonomic group in different treatments of thinning intensity, canopy tree species, and decay class (taxonomic groups with significant differences in bold, $n=36, p<0.05$ ).

\begin{tabular}{|c|c|c|c|c|c|c|c|}
\hline \multirow{2}{*}{ Taxa } & \multicolumn{3}{|c|}{ Thinning Intensity } & \multicolumn{2}{|c|}{ Canopy Type } & \multicolumn{2}{|c|}{ Decay Class } \\
\hline & $0 \%$ & $20 \%$ & $40 \%$ & Mixed & Pure Pine & Class 3 & Class 4 \\
\hline Oribatid mites & $0.846 \pm 0.37$ & $1.023 \pm 0.43$ & $0.601 \pm 0.19$ & $0.881 \pm 0.26$ & $0.765 \pm 0.30$ & $0.211 \pm 0.05$ & $1.435 \pm 0.33$ \\
\hline Other mites & $0.797 \pm 0.24$ & $0.393 \pm 0.17$ & $0.676 \pm 0.37$ & $0.530 \pm 0.15$ & $0.714 \pm 0.27$ & $0.116 \pm 0.04$ & $1.128 \pm 0.26$ \\
\hline Mites: Immature & $2.860 \pm 1.10$ & $1.896 \pm 0.65$ & $1.117 \pm 0.51$ & $1.683 \pm 0.48$ & $2.233 \pm 0.85$ & $0.651 \pm 0.20$ & $3.265 \pm 0.84$ \\
\hline Macrofauna: larvae & $0.038 \pm 0.01$ & $0.064 \pm 0.03$ & $0.040 \pm 0.01$ & $0.038 \pm 0.01$ & $0.056 \pm 0.02$ & $0.044 \pm 0.01$ & $0.051 \pm 0.01$ \\
\hline Collembola & $0.828 \pm 0.30$ & $0.686 \pm 0.38$ & $0.563 \pm 0.26$ & $0.759 \pm 0.26$ & $0.625 \pm 0.25$ & $0.154 \pm 0.07$ & $1.231 \pm 0.31$ \\
\hline Diptera & $0.008 \pm 0.00$ & $0.006 \pm 0.00$ & $0.007 \pm 0.00$ & $0.010 \pm 0.00$ & $0.005 \pm 0.00$ & $0.003 \pm 0.00$ & $0.011 \pm 0.00$ \\
\hline Geophilomorpha & $0.008 \pm 0.01$ & $0.005 \pm 0.00$ & $0.002 \pm 0.00$ & $0.008 \pm 0.00$ & $0.002 \pm 0.00$ & $0.000 \pm 0.00$ & $0.010 \pm 0.00$ \\
\hline Hymenoptera & $0.018 \pm 0.01$ & $0.002 \pm 0.00$ & $0.009 \pm 0.00$ & $0.007 \pm 0.00$ & $0.013 \pm 0.00$ & $0.012 \pm 0.01$ & $0.008 \pm 0.00$ \\
\hline Oligochaeta & $0.004 \pm 0.00$ & $0.000 \pm 0.00$ & $0.000 \pm 0.00$ & $0.000 \pm 0.00$ & $0.003 \pm 0.00$ & $0.000 \pm 0.00$ & $0.003 \pm 0.00$ \\
\hline Symphyla & $0.011 \pm 0.01$ & $0.008 \pm 0.00$ & $0.007 \pm 0.00$ & $0.014 \pm 0.00$ & $0.004 \pm 0.00$ & $0.004 \pm 0.00$ & $0.014 \pm 0.00$ \\
\hline Thysanoptera & $0.006 \pm 0.00$ & $0.000 \pm 0.00$ & $0.000 \pm 0.00$ & $0.003 \pm 0.00$ & $0.000 \pm 0.00$ & $0.000 \pm 0.00$ & $0.003 \pm 0.00$ \\
\hline Araneae & $0.006 \pm 0.00$ & $0.002 \pm 0.00$ & $0.010 \pm 0.01$ & $0.011 \pm 0.01$ & $0.001 \pm 0.00$ & $0.000 \pm 0.00$ & $0.011 \pm 0.01$ \\
\hline Pseudoscorpionidae & $0.000 \pm 0.00$ & $0.001 \pm 0.00$ & $0.000 \pm 0.00$ & $0.001 \pm 0.00$ & $0.000 \pm 0.00$ & $0.001 \pm 0.00$ & $0.000 \pm 0.00$ \\
\hline Lithobiomorpha & $0.006 \pm 0.01$ & $0.001 \pm 0.00$ & $0.000 \pm 0.00$ & $0.000 \pm 0.00$ & $0.005 \pm 0.00$ & $0.000 \pm 0.00$ & $0.005 \pm 0.00$ \\
\hline Pauropoda & $0.012 \pm 0.01$ & $0.000 \pm 0.00$ & $0.000 \pm 0.00$ & $0.000 \pm 0.00$ & $0.008 \pm 0.01$ & $0.000 \pm 0.00$ & $0.008 \pm 0.01$ \\
\hline $\begin{array}{l}\text { Undescribed } \\
\text { Chilopoda }\end{array}$ & $0.004 \pm 0.00$ & $0.002 \pm 0.00$ & $0.000 \pm 0.00$ & $0.001 \pm 0.00$ & $0.003 \pm 0.00$ & $0.000 \pm 0.00$ & $0.004 \pm 0.00$ \\
\hline Coleoptera & $0.004 \pm 0.00$ & $0.040 \pm 0.03$ & $0.007 \pm 0.00$ & $0.011 \pm 0.01$ & $0.023 \pm 0.02$ & $0.013 \pm 0.00$ & $0.021 \pm 0.02$ \\
\hline Nematoda & $0.000 \pm 0.00$ & $0.001 \pm 0.00$ & $0.000 \pm 0.00$ & $0.000 \pm 0.00$ & $0.001 \pm 0.00$ & $0.000 \pm 0.00$ & $0.001 \pm 0.00$ \\
\hline Hemiptera & $0.000 \pm 0.00$ & $0.000 \pm 0.00$ & $0.001 \pm 0.00$ & $0.000 \pm 0.00$ & $0.000 \pm 0.00$ & $0.000 \pm 0.00$ & $0.000 \pm 0.00$ \\
\hline
\end{tabular}

There was also a higher water content under the mixed canopy than under the pine canopy, but differences were not significant. On the other hand, a significant interaction among the three variables indicated that decay class 4 samples in $40 \%$ thinning under pine canopy had the lowest coarse woody debris (CWD) water content $(\mathrm{GLM}$ result: $Z=4.706, p<0.001)$ (Table 5 ).

Table 5. Mean and SE number of captured individuals per gram of CWD in different treatments of thinning intensity, canopy type, and CWD decay class (significant differences at $p<0.05$ in bold, $n=36$ ).

\begin{tabular}{|c|c|c|c|c|c|c|c|c|c|c|}
\hline \multirow[t]{2}{*}{ Variable } & \multicolumn{4}{|c|}{ Thinning Intensity } & \multicolumn{3}{|c|}{ Canopy Type } & \multicolumn{3}{|c|}{ CWD Decay Class } \\
\hline & $0 \%$ & $20 \%$ & $40 \%$ & $p$ & Mixed & Pure Pine & $p$ & Class 3 & Class 4 & $p$ \\
\hline Water content $(\%)$ & $56.10 \pm 11.63$ & $57.84 \pm 20.20$ & $45.54 \pm 11.51$ & 0.695 & $60.45 \pm 8.75$ & $60.20 \pm 17.04$ & 0.462 & $31.27 \pm 8.33$ & $89.47 \pm 13.30$ & 0.002 \\
\hline 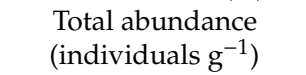 & $5.46 \pm 6.52$ & $4.14 \pm 5.44$ & $3.04 \pm 3.93$ & 0.671 & $3.97 \pm 4.91$ & $3.20 \pm 4.61$ & 0.155 & $1.32 \pm 1.67$ & $5.86 \pm 5.63$ & $<0.001$ \\
\hline $\begin{array}{c}\text { Richness } \\
\text { (number of taxa) }\end{array}$ & $6.83 \pm 2.37$ & $6.33 \pm 2.35$ & $5.83 \pm 1.99$ & 0.571 & $7.08 \pm 1.62$ & $5.08 \pm 2.19$ & 0.031 & $5.42 \pm 1.98$ & $6.75 \pm 2.78$ & 0.008 \\
\hline Shannon-Wiener Index & $1.20 \pm 0.28$ & $1.11 \pm 0.29$ & $1.17 \pm 0.39$ & 0.742 & $1.07 \pm 0.35$ & $1.18 \pm 0.40$ & 0.837 & $1.13 \pm 0.34$ & $1.14 \pm 0.35$ & 0.899 \\
\hline
\end{tabular}




\subsection{Canopy Type Influence on Invertebrate Community}

Fourteen taxonomic groups were registered under the mixed canopy but 16 under the pine dominated canopy. A tendency to higher absolute abundance under the mixed canopy was observed for eight taxa: oribatid mites, Collembola, Diptera, Geophilomorpha, Symphyla, Thysanoptera, Araneae and Pseudoscorpionidae. Furthermore, Thysanoptera and Pseudoscorpionidae were only registered under mixed canopy.

On the other hand, a tendency to higher absolute abundance under pine canopy was observed for most of the taxonomic groups registered in this study (10 taxa): other mites, immature mites, immature stages of macrofauna (larvae), Hymenoptera, Oligochaeta, Lithobiomorpha, Pauropoda, unidentified Chilopoda, Coleoptera, and Nematoda. In fact, Oligochaeta, Lithobiomorpha, Pauropoda, and Nematoda were only registered under pure pine canopy (Table 4). In spite of these trends, the results of the Kruskal-Wallis tests indicated significant influence of canopy type only for Collembola $\left(X_{d f 1}^{2}=4.016, p=0.045\right)$ and Symphyla $\left(X^{2} d f 1=4.016, p=0.012\right)$.

Species richness was significantly higher in mixed patches than in pure pine patches $\left(X^{2} d f 1=4.016\right.$, $p=0.031$ ). However, no significant differences between canopy types were found for total abundance and the Shannon-Wiener index (Table 5). In addition, GLM results indicated that the interaction between pure pine canopy and decay class significantly affected total abundance, with the highest decomposed CWD (class 4) under pine canopy having the lowest abundance $(Z=2.148, p=0.032)$.

\subsection{CWD Decay Class Influence on Invertebrate Community Composition}

Ten taxonomic groups were recorded in the CWD decay class 3 and 17 taxonomic groups in the decay class 4 (Table 3). All taxa except Hymenoptera and Pseudoscorpionidae showed higher abundances in class 4 than in class 3. However, Geophilomorpha, Oligochaeta, Thysanoptera, Araneae, Lithobiomorpha, Pauropoda, undescribed Chilopoda, and Nematoda were only registered in this decay class 4.

Nevertheless, CWD decay class significantly influenced oribatid mites $\left(X_{d f 1}^{2}=17.974, p<0.001\right)$, other mites $\left(X_{d f 1}^{2}=16.153, p<0.001\right)$, immature mites $\left(X_{d f 1}^{2}=7.772, p=0.005\right)$, Collembola $\left(X_{d f 1}^{2}=11.157\right.$, $p=0.001)$, immature stages macrofauna (larvae) $\left(X_{d f 1}^{2}=4.982, p=0.026\right)$, Geophilomorpha $\left(X_{d f 1}^{2}=5.605\right.$, $p=0.018)$, and Symphyla $\left(X_{d f 1}^{2}=3.947, p=0.047\right)$. Although the Shannon-Wiener index was not significantly different between decay classes, total abundance $\left(X^{2} d f 1=16.400, p<0.001\right)$ and richness were significantly influenced by them $\left(X^{2} d f 1=7.123, p=0.008\right)$. Regarding water content, it was significantly higher in class 4 than in class $3\left(X_{d f 1}^{2}=8845, p=0.003\right)$ (Table 4$)$.

\subsection{Correlations between Taxa, Total Abundance, and Water Content}

CWD water content had positive correlations with abundance of oribatid, other mites, Collembola, immature mites, and total abundance of invertebrates, whereas the abundance of oribatid mites had a positive correlation with other mites, Collembola, immature mites, and total abundance of invertebrates. On the other hand, the abundance of other mites had positive correlations with the abundance of Collembola, immature mites, and total abundance of invertebrates. The order Collembola as well showed high positive correlations with immature mites and total abundance of invertebrates. Finally, the abundance of immature mites had a positive correlation with total abundance (Figure 2). 


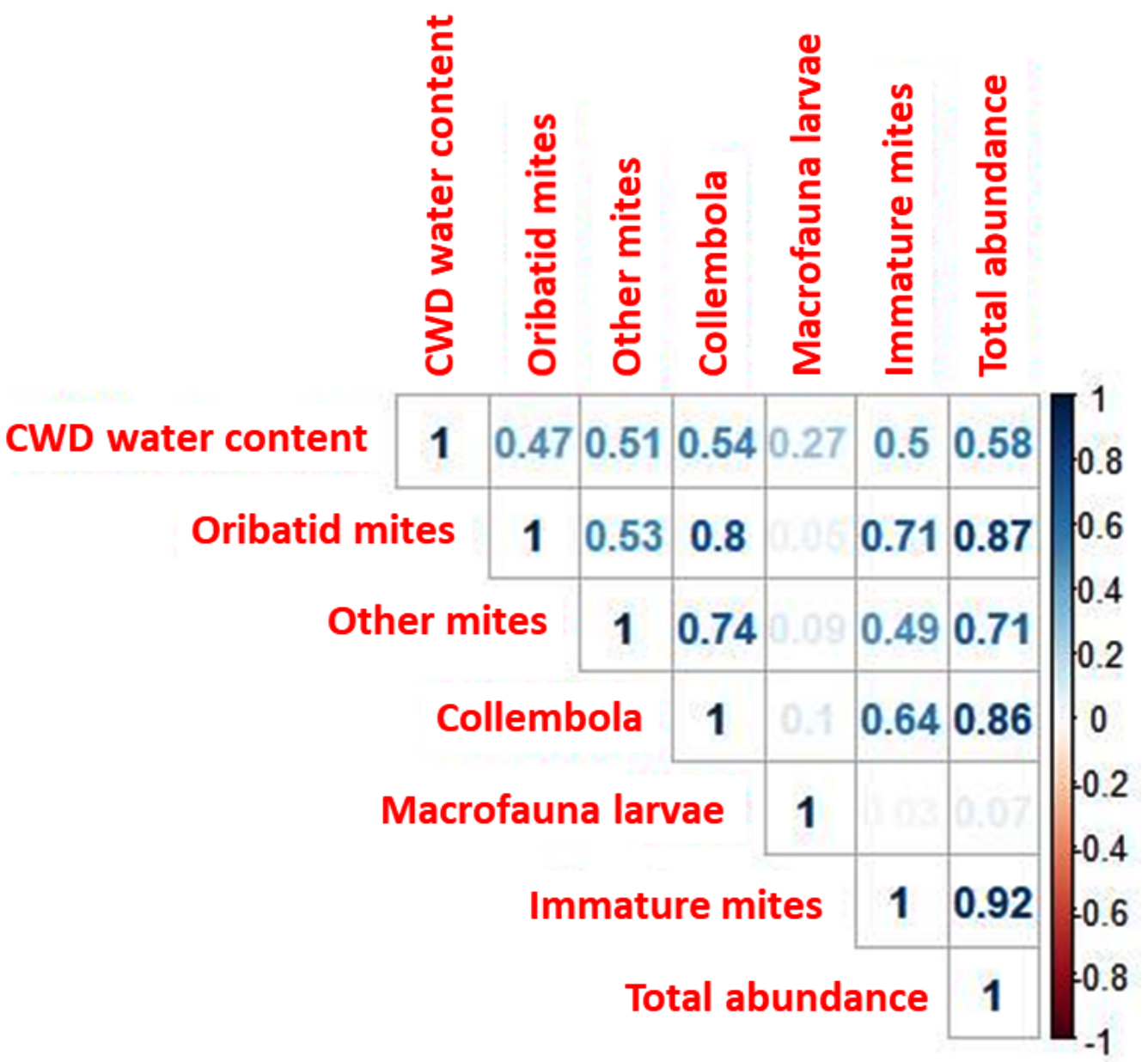

Figure 2. Correlations matrix considering the variables that represented a higher variance (\%) in forest thinning, canopy type and decay class of coarse woody debris (CWD).

The strong correlations between the taxonomic groups displayed in Figure 2 are also well represented in the PCA biplot (Figure 3), where the horizontal axis (Dim1) explains the $62.3 \%$ of the total variability, and the vertical axis (Dim2) explains the $15.4 \%$ of variability in the data set. The response variables: other mites, Collembola, total abundance of invertebrates, oribatid mites, and immature mites were strongly correlated among them and with the Dim1 (decay class 4), whereas the immature stages of macrofauna (larvae) did not present a higher correlation with the other response variables and it is explained for the Dim 2. 


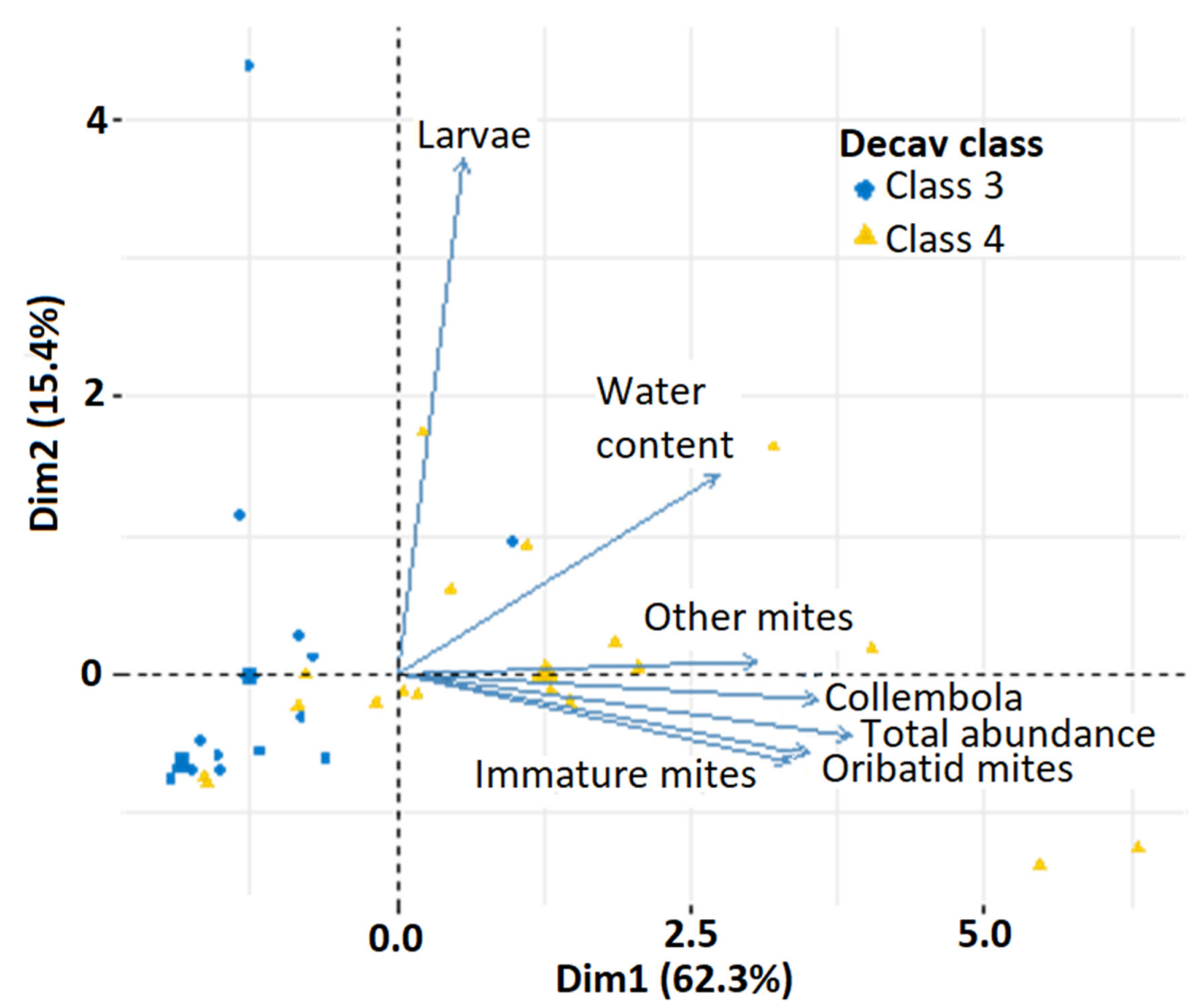

Figure 3. PCA-biplot of CWD decay class for total abundance considering the variables that represented a higher variance: CWD water content, oribatid mites, other mites, Collembola, immature stages of macrofauna (larvae), immature mites, and total abundance of invertebrates. The horizontal axis (Dim1); the vertical axis (Dim2). Decav class: CWD decomposition class.

\section{Discussion}

\subsection{Invertebrate Community Composition}

In this study, we registered a total of 19 taxonomic groups in coarse woody debris (class 3 and class 4). CWD class 4 (advanced decomposition) had higher richness and abundance, as both decay classes had different wood structural properties [7]. However, five microinvertebrate taxonomic groups represented $96.75 \%$ of the total abundance (oribatid mites, other mites, immature mites, Collembola, and Nematoda), whereas the 14 macroinvertebrate taxonomic groups only represented the other $3.25 \%$.

Previous research has reported the presence of these taxonomic groups in soil and leaf litter across this region [29,43-45]. Nevertheless, it is important to take into consideration that our results just report these taxonomic groups in mid-spring of 2015, and therefore, more data collection in different times of the year would be needed to understand seasonal changes. If the sampling would be repeated in summer, we may expect less presence of immature mites and macrofauna larvae, as they would have had more time to finish their growth and development cycles. In addition, the mesh size of the Berlese-Tullgren funnel $(\sim 2 \mathrm{~mm})$ may have prevented macroinvertebrates of bigger body size from being captured. In any case, the similitude among orders found in the leaf litter [29] and CWD from the same site may indicate some degree of migration between substrates.

Although our taxonomic identification may not be enough to assign feeding habits to several of the taxa listed, it is worth highlighting that Collembola and oribatid mites, which account for $35 \%$ of total abundance, are panphitophagous [46], suggesting that these taxonomic groups could have a wide diet and therefore a wide habitat use in coarse woody debris. For other taxa, 
some macroinvertebrates taxonomic groups registered in this research belong to different feeding groups, but in general, they usually are predators or carnivores (Pseudoscorpionidae, Araneae, Geophilomorpha, and Lithobiomorpha with the exception of Thysanoptera) [47-49]. The diversity of dietary habitats could indicate the establishment of a working complex trophic network as CWD follow their decomposition process and the easiness of colonization increases from classes 3 to class 4. On the other hand, the low percentage of macrofauna larvae compared to the total abundance (but relatively high compared to only macrofauna abundance) could be related to the timing of sample collection (mid-spring). Nevertheless, this also points to the well-known fact that many taxonomic groups use CWD to complete their larval cycle [1].

\subsection{Thinning Influence on Invertebrate Community Composition}

In this study, with the exception of Thysanoptera, thinning did not significantly influence species richness, total abundance, and the Shannon-Wiener index. However, richness and total abundance consistently decreased as thinning intensity increased, which could be related to the clear reduction in CWD moisture (albeit not significant, probably due to a reduced sample size) as stand density is reduced and therefore radiation and wind can dry CWD, particularly under pine canopies.

Such phenomenon has been reported at the same site for leaf litter [20]. Being a Mediterranean site, if the sampling would be repeated in summer (dry season) we may expect clearer differences among thinning treatments under pine canopy as the higher radiation in thinned plots would desiccate CWD more. However, under mixed canopy, differences may not occur, as beech leaves would have had their maximum expansion therefore shadowing the forest floor. In addition, under mixed canopies no influence of thinning on throughfall were detected [40], and therefore, thinning influence on CWD moisture is not clear.

An exception were oribatid mites and immature stages of macrofauna (larvae), which presented the highest abundance in the $20 \%$ thinning intensity plots. This result could be related to the moistureradiation balance at these plots, which may be optimal. Interestingly, a similar pattern has been reported for pine growth $[14,40]$ and for understory diversity [50,51], with the highest values consistently found at the $20 \%$ thinning plots. Such similar results for trees, plants, and invertebrates may support the case for the $20 \%$ thinning intensity as the most suitable from a biodiversity maintenance point of view.

The decrease of taxonomic groups and abundance of invertebrates associated to CWD under thinning (albeit not significant, likely due to small sample size) may have implications in the decomposition rate of this substratum. A lower invertebrate community under the heavy thinning $(40 \%)$ could result in a lower consumption of CWD, as the absence of certain taxonomic groups leaves certain substrate fractions intact as it has been reported in leaf litter [52]. Similar results were found for leaf litter decay rates in the same research plots with heavy thinning slowing down decomposition, the cumulative effects of mesofauna reduction in leaf litter being one of the possible factors [20]. Therefore, we can cautiously accept our first initial hypothesis, as thinning has been found as a significant factor but only through interactions with other variables.

\subsection{Canopy Type Influence on Invertebrate Community Composition}

Species richness and densities of Collembola and Symphyla were significantly affected by canopy type, their values being higher under mixed canopy. It is well known that canopy architecture influences understory light radiation and humidity, as the entrance of direct radiation and throughfall to the understory depends on the location of the canopy openings and canopy height. The light environment in which CWD are placed is in general darker under the mixed canopy than under pure pine canopy [53], favoring for CWD under mixed canopy to retain moisture for longer time, increasing richness and densities of certain taxa. These results could also be related to foliage diet (palatability and litter quality) for those taxa that could feed not only in decomposing wood but also on decomposing leaf litter, which would be different under each canopy type [54,55]. Finally, increases in invertebrate richness could be related to microhabitat heterogeneity, which could be higher under mixed canopy. 
In addition, we registered higher water content of coarse woody debris under mixed canopy than under pine canopy. As discussed in the case of thinning, differences in CWD moisture and in the moisture-radiation balance between canopy types may be fueling the observed differences in invertebrate communities under mixed and pine canopies. Hence, considering our results, we can accept our second initial hypothesis.

\subsection{CWD Decay Class Influence on Invertebrate Community Composition}

Unsurprisingly, decay class was the most important factor explaining the invertebrate community structure in CWD. Total abundance and species richness of oribatid mites, other mites, immature mites, Collembola, immature stages of macrofauna (larvae), Geophilomorpha, and Symphyla were significantly higher in the decay class 4 than in the decay class 3 , indicating that the invertebrate community composition is more diverse when coarse woody debris are in advanced decay classes. Such fact can be related to higher water availability of deadwood that make wood softer and easier to decompose, more palatable, and more nutritive for many invertebrate taxonomic groups. The development of an increasingly complex trophic network allows for a higher number of taxa, in which more xaprophagous, panphitophagous, frugivorous, predators, and parasitoids can be found in the most decomposed classes [11].

\subsection{Interactions among Variables and Management Implications}

GLM results indicated an important fact: although no direct thinning effects were found, when interacting with other variables, thinning can have a significant influence on the CWD colonization process by mesofauna. In addition, the PCA results suggested as well that CWD water content was strongly correlated with mites and Collembola (particularly in the advanced stages of wood decomposition). As these taxa account for the majority of identified individuals, total abundance is also related to water content. In addition, these results could indicate water limitation of these taxonomic groups for their survival, which is not surprising being the taxa with the smallest body size, and therefore less able to store water in their bodies. In addition, the correlation with water content is likely also related to the Mediterranean nature of the site, with an important dry season during the summer months.

Hence, the modulation of CWD water content by forest management (thinning and canopy type) has been the likely cause of the observed changes. However, the direction and magnitude of such changes are not easy to predict, as our GLM results show. Controlling stand density by thinning could reduce CWD water content under a coniferous canopy as CWD are exposed to radiation and wind. However, under mixed conifer-broadleaf canopy in which a species such as European beech can expand its crown in detriment of Scots pine [56], thinning could actually have the opposite effect. In addition, these effects can change over time, as a moist CWD class 3 could be quickly colonized, generating a CWD class 4 with higher relative surface due to boring and drilling, which in turn could cause faster desiccation in a Mediterranean environment with greatly variable precipitation in late spring-early summer. Overall, in a context of maximizing soil arthropod biodiversity and incorporation of woody biomass into the forest floor, a moderate thinning that leaves CWD for decomposition on site could be recommended.

In addition, modifying litterfall composition and production rate with thinning or changes in canopy type $[20,56]$ could also modify CWD mesofauna communities, as they are also directly connected to litter communities and vice versa [57]. Under the current paradigm of moving from pure to mixed Scots pine-European beech forests in Europe [15,16], our results should be taken into account both from the biodiversity perspective and from the carbon and nutrient cycling perspective [2], as invertebrate communities influence CWD decay rates [9,57-59]. Consequently, we recommend considering the ecological role of CWD mesofauna when planning silvicultural practices, particularly in mixed forests. 


\section{Conclusions}

Coarse woody debris (CWD) play multiple important roles in the ecosystem, such as habitat for species and nutrients soil input. Our results provide some of the first evidence of the interactive effects that overstory composition and thinning can have an impact on CWD invertebrate taxonomic groups and richness in mixed forests of the two European tree species more widely distributed (Pinus sylvestris and Fagus sylvatica L.). As thinning and type of canopy cover modifies the moisture-radiation-wind balance in the forest soil, CWD moisture content seems to be reduced when tree density reduction crosses a threshold around $20 \%$ of initial basal area. Such change can affect differently invertebrate taxa, with some being more sensitive to moisture reduction than others are. In addition, the time that CWD have been decomposing (decay classes) exerts the most important influence on the invertebrate community, as it is directly linked to the physicochemical conditions of CWD.

Author Contributions: X.H.-A. carried out the fieldwork, implemented the data analysis, and interpreted the results. J.A.B. and J.B.I. designed the experiment, collaborated with the fieldwork and interpreted the results. W.A. participated in data analysis and interpretation. G.R.-B. collaborated in the discussion of the results. All the authors participated in the writing of the manuscript. All authors have read and agreed to the published version of the manuscript.

Funding: This work has been funded through the AGL2012-33465 projects of the Ministry of Economy and Competitiveness, and the CIG-2012-326718-ECOPYREN3 project of the Marie Curie Actions of the 7th Framework Program of the European Commission. The first author of this article conducted this research during her MSc. thesis at the Public University of Navarre sponsored by the grants of the Carolina Foundation of Spain. Published with the support of the Marie Curie Alumni Association.

Acknowledgments: We appreciate the collaboration of Yueh-Hsin Lo and Ester González de Andrés in different tasks related to this research. In memoriam of Vlastimil Zak, an exceptional Ecuadorian Botanist.

Conflicts of Interest: The authors declare no conflict of interest.

\section{References}

1. Harmon, M.; Franklin, J.; Swanson, F.; Sollins, P.; Gregory, S.; Lattin, J.; Anderson, N.; Cline, S.; Aumen, N.; Sedell, J.; et al. Ecology of coarse woody debris in temperate ecosystems. Adv. Ecol. Res. 1986, 15, 133-302.

2. Harmon, M.E.; Fasth, B.G.; Yatskov, M.; Kastendick, D.; Rock, J.; Woodwall, C.W. Release of coarse woody detritus-related carbon: A synthesis across forest biomes. Carbon Balance Manag. 2020, 15, 1-21. [CrossRef]

3. Frank, S.; Steyaert, S.; Swenson, J.; Storch, I.; Kindberg, J.; Barck, H.; Zedrosser, A. A “clearcut”case? Brown bear selection of coarse woody debris and carpenter ants on clearcuts. For. Ecol. Manag. 2015, 348, $164-173$. [CrossRef] [PubMed]

4. Sullivan, T.; Sullivan, D.; Sullivan, J.-R. Mammalian responses to windrows of woody debris on clear-cuts: Abundance and diversity of forest-floor small mammals and presence of small mustelids. For. Ecol. Manag. 2017, 399, 143-154. [CrossRef]

5. Riffel, S.; Verschuyl, J.; Miller, D.; Wigley, T. Biofuel harvests, coarse woody debris, and biodiversityA meta-analysis. For. Ecol. Manag. 2011, 261, 878-887. [CrossRef]

6. Hanula, J. Relationship of wood-feeding insects and coarse woody debris. In Biodiversity and Coarse Woody Debris in Southern Forests; USDA General Technical Report SE-94, Southeast; US Department of Agriculture Forest Service, Southern Research Station: Asheville, NC, USA, 1996; pp. 55-81.

7. Waddell, K. Sampling coarse woody debris for multiple attributes in extensive resource inventories. Ecol. Ind. 2002, 1, 139-153. [CrossRef]

8. Savely, H. Ecological relations of certain animals in dead pine and oak logs. Ecol. Monogr. 1939, 9, $322-385$. [CrossRef]

9. Magnússon, R.I.; Tietema, A.; Cornelissen, J.H.C.; Hefting, M.M.; Kalbitz, K. Tamm Review: Sequestration of carbon from coarse woody debris in forest soils. For. Ecol. Manag. 2016, 377, 1-15. [CrossRef]

10. Fager, E. The community of invertebrates in decaying oak wood. J. Anim. Ecol. 1968, 7, 121-142. [CrossRef]

11. Vanderwel, M.; Malcolm, J.; Smith, S.; Islam, N. Insect community composition and trophic guild structure in decaying logs from eastern canadian pine-dominated forests. For. Ecol. Manag. 2006, 225, 190-199. [CrossRef] 
12. Radtke, P.J.; Amateis, R.L.; Prisley, S.P.; Copenheaver, C.A.; Pittman, J.R.; Burkhart, H.E. Modeling production and decay of coarse woody debris in loblolly pine plantations. For. Ecol. Manag. 2009, 257, 790-799. [CrossRef]

13. Fujimori, T. Ecological and Silvicultural Strategies for Sustainable Forest Management; Elsevier Science: Amsterdam, The Netherlands, 2001.

14. Primicia, I.; Camarero, J.J.; Imbert, J.B.; Castillo, F.J. Effects of thinning and canopy type on growth dynamics of Pinus sylvestris: Inter-annual variations and intra-annual interactions with microclimate. Eur. J. For. Res 2013, 132, 121-135. [CrossRef]

15. González de Andrés, E. Interactions between climate and nutrient cycles on forest response to global change: The role of mixed forests. Forests 2019, 10, 609. [CrossRef]

16. Pretzsch, H.; Del Río, M.; Ammer, C.; Avdagic, A.; Barbeito, I.; Bielak, K.; Brazaitis, G.; Coll, L.; Dirnberger, G.; Drössler, L.; et al. Growth and yield of mixed versus pure stands of Scots pine (Pinus sylvestris L.) and European beech (Fagus sylvatica L.) analysed along a productivity gradient through Europe. Eur. J. For. Res. 2015, 134, 927-947. [CrossRef]

17. Coleman, D.C.; Whitman, W.B. Linking species richness, biodiversity and ecosystem function in soils systems. Pedobiologia 2005, 49, 479-497. [CrossRef]

18. Blanco, J.A.; Imbert, J.B.; Castillo, F.J. Influence of site characteristics and thinning intensity on litterfall production in two Pinus sylvestris L. forests in the Western Pyrenees. For. Ecol. Manag. 2006, 237, 342-352. [CrossRef]

19. Blanco, J.A.; Imbert, J.B.; Castillo, F.J. Nutrient return via litter fall in two contrasting Pinus sylvestris forests in the pyrenees under different thinning intensities. For. Ecol. Manag. 2008, 256, 1840-1852. [CrossRef]

20. Blanco, J.A.; Imbert, J.B.; Castillo, F.J. Thinning affects Pinus sylvestris needle decomposition rates and chemistry differently depending on site conditions. Biogeochemistry 2011, 106, 397-414. [CrossRef]

21. Martínez, C. Influencia de las Claras Forestales en la Producción de Restos Leñosos en Bosques de pino Silvestre del Pirineo Navarro. Master's Thesis, Public University of Navarre, Pamplona, Spain, 2015.

22. Herrera-Alvarez, X. Influencia de las Claras Forestales en los Restos Leñosos de Pino Silvestre en un Bosque Mixto en Aspurz: Un Enfoque e Volumen, Biomasa y Hábitat de Invertebrados. Master's Thesis, Public University of Navarre, Pamplona, Spain, 2015.

23. Fravoline, G.; Tognetti, R.; Lombardi, F.; Egli, M.; Ascher-Jenull, J.; Arfaioli, P.; Bardellin, T.; Cherubini, P.; Marchetti, M. Quantifying decay progression of deadwood in Mediterranean mountain forests. For. Ecol. Manag. 2018, 408, 228-237. [CrossRef]

24. Gonsalves, L.; Law, B.; Brassil, T.; Waters, C.; Toole, I.; Tap, P. Ecological outcomes for multiple taxa from silvicultural thinning of regrowth forest. For. Ecol. Manag. 2018, 425, 177-188. [CrossRef]

25. Schowalter, T.; Zhang, Y.; Rykken, J. Litter invertebrate responses to variable density thinning in western Washington forest. Ecol. Appl. 2003, 13, 1204-1211. [CrossRef]

26. Sipos, J.; Hédl, R.; Hula, V.; Chudomelova, M.; Kosulic, O.; Niedobova, J.; Riedl, V. Patterns of functional diversity of two trophic groups after canopy thinning in an abandoned coppice. Folia Geobotanica 2017, 52, 45-58. [CrossRef]

27. Kosulic, O.; Michalko, R.; Hula, V. Impact of canopy openness on spider communities: Implications for conservation management of formerly coppiced oak forests. PLoS ONE 2016, 11, eo148585. [CrossRef] [PubMed]

28. Perry, K.; Herms, D. Response of the forest floor invertebrate community to canopy gap formation caused by early stages of emerald ash borer-induced ash mortality. For. Ecol. Manag. 2016, 375, 259-267. [CrossRef]

29. Jabat, U. Influencia de la Intensidad de Clara, el Tipo de Dosel Arbóreo y las Hozaduras de Jabalí, en la Descomposición de Hojarasca y Colonización por Mesofauna de un Bosque Mixto del Pirineo Navarro. Master's Thesis, Public University of Navarre, Pamplona, Spain, 2006.

30. Marturet, S. Influencia de la Intensidad de Clara y Tipo de Dosel Arbóreo Sobre la Descomposición y Respiración del Suelo en un Bosque Mixto del Pirineo Navarro. Master's Thesis, Public University of Navarre, Pamplona, Spain, 2016.

31. González de Andrés, E.; Seely, B.; Blanco, J.A.; Imbert, J.B.; Lo, Y.H.; Castillo, F.J. Increased complementarity in water-limited environments in scots pine and European beech mixtures under climate change. Ecohydrology 2017, 10, e1810. [CrossRef] 
32. Euforgen. Distribution Map of Scots Pine (Pinus sylvestris L.). Available online: http://www.euforgen.org/ species/pinus-sylvestris/ (accessed on 12 August 2020).

33. Government of Navarre. Meteorología y Climatología de Navarra. Available online: http://meteo.navarra. es/climatologia/selfichaclima.cfm?IDEstacion=178\&tipo=MAN (accessed on 12 August 2020).

34. Blanco, J.A. La Práctica de las Claras Forestales y su Influencia en el Ciclo Interno de Nutrientes en dos Bosques de Pino Silvestre de los Pirineos Navarros. Ph.D. Thesis, Public University of Navarre, Pamplona, Spain, 2004.

35. Primicia, I. Influence of Thinning and Canopy Type on the Internal Nutrient Cycling and the Secondary Growth of Pinus Sylvestris 1. in a Mixed Forest in the Pyrenees. Ph.D. Thesis, Public University of Navarre, Pamplona, Spain, 2012.

36. Papadakis, J. Climates of the World, Their Classification, Similitudes, Differences, and Geographic Distribution; Self-Edited: Buenos Aires, Argentina, 1970.

37. Blanco, J.A.; Zavala, M.A.; Imbert, J.B.; Castillo, F.J. Sustainability of forest management practices: Evaluation through a simulation model of nutrient cycling. For. Ecol. Manag. 2005, 213, 209-228. [CrossRef]

38. Candel-Pérez, C.; Lo, Y.H.; Blanco, J.A.; Chiu, C.M.; Camarero, J.J.; de Andrés, E.G.; Imbert, J.B.; Castillo, F.J. Drought-induced changes in wood density are not prevented by thinning in scots pine stands. Forests 2018, 9, 4. [CrossRef]

39. Garcia Sancet, M.A. Influencia de los Parámetros de Dosel y Lumínicos Sobre la Regeneración de Pinus sylvestris L. en un Bosque Mixto Con Tres Intensidades de Clara. Master's Thesis, Public University of Navarre, Pamplona, Spain, 2017.

40. Cardil, A.; Imbert, J.B.; Camarero, J.J.; Primicia, I.; Castillo, F.J. Temporal interactions among throughfall, type of canopy and thinning drive radial growth in an Iberian mixed pine-beech forest. Agric. For. Meteor. 2018, 252, 63-74. [CrossRef]

41. Barrientos, J. Bases Para un Curso Práctico de Entomología; Asociación Española de Entomología: Barcelona, Spain, 1988.

42. Swift, M.; Heal, O.; Anderson, J. Decomposition in Terrestrial Ecosystems; Blackwell Scientific: Oxford, UK, 1979.

43. Groombridge, B. Soil Microfauna. In Global Biodiversity: Status of the Earth's Living Resources; World Conservation Monitoring Centre, Ed.; Chapman \& Hall: London, UK, 1992; pp. 103-115.

44. Arzuaga Iribarren, M. Influencia de la Intensidad de Clara, el Tipo de Dosel Arbóreo y Las Hozaduras de Jabalí en Las Variables Fisico-Químicas y los Microartrópodos del Suelo de un Bosque Mixto. Master's Thesis, Public University of Navarre, Pamplona, Spain, 2005.

45. Garai Iturri, I. Influencia del Aclareo en la Colonización y Descomposición de Hojarasca de Pinus sylvestris L. por Microartropodos en dos Bosques del Pirineo Navarro. Master's Thesis, Public University of Navarre, Pamplona, Spain, 2004.

46. Salazar, M.; Accattoli, C.; Martínez, P.; Schack, J. Nuevas citas de ácaros oribátidos (Acari: Oribatid) para la argentina. Rev. Soc. Entomol. Argent. 2006, 65, 19-22.

47. Hibbert, A. Importance of Fallen Coarse Woody Debris to the Diversity of Saproxylic Diptera in the Boreal Mixedwood Forests of Eastern North America. Master's Thesis, Université du Québec à Montréal, Montreal, QC, Canada, 2001.

48. Moldenke, A. Natural Resources Conservation Service Soils. Natural Resources Conservation Service, United States Department of Agriculture. Available online: https:/www.nrcs.usda.gov/wps/portal/nrcs/detailfull/ soils/health/biology/?cid=nrcs142p2_05386 (accessed on 12 August 2020).

49. Lizotte, R. Desert Museum Arizona, Sonora. Available online: https://www.desertmuseum.org/books/nhsd_ centipede.php (accessed on 12 August 2020).

50. Blanco, J.A.; Imbert, J.B.; Castillo, F.J. Cambios en el sotobosque de pinares en los pirineos occidentales bajo distintas intensidades de clara. In Proceedings of the 3rd Spanish forest Congress, Sierra Nevada 2001, Granada, Spain, 25-29 September 2001; Volume 1, pp. 340-345.

51. Imbert, J.B.; Blanco, J.A.; Valladares, F.; Castillo, F.J. Influence of thinning on plant species richness and diversity, and solar radiation indices in two contrasting Iberian Pinus sylvestris L. forests during a five year period. In Proceedings of the First Diversitas Open Science Conference “Integrating Biodiversity Science for Human Well-Being", Oaxaca, Mexico, 9-12 November 2005.

52. González, G.; Seastedt, T. Soil fauna and plant litter decomposition in tropical and subalpine forest. Ecology 2001, 82, 955-964. [CrossRef] 
53. Valladares, F. La disponibilidad de luz bajo el dosel de los bosques y matorrales ibéricos estimada mediante fotografía hemisférica. Ecología 2006, 20, 11-30.

54. Andre, H.; Voegtlin, D. Some observations on the biology of Camisia carrolli (Acari:Oribatid). Acarologia 1981, $23,81-89$.

55. Castro, A.; Wise, D.H. Influence of fallen coarse woody debris on the diversity and community structure of forest-floor spiders (Arachnida: Araneae). For. Ecol. Manag. 2010, 260, 2088-2101. [CrossRef]

56. De Andrés, E.G.; Blanco, J.A.; Imbert, J.B.; Guan, B.T.; Lo, Y.H.; Castillo, F.J. ENSO and NAO affect long-term leaf litter dynamics and stoichiometry of Scots pine and European beech mixedwoods. Glob. Chang. Biol. 2019, 25, 3070-3090. [CrossRef] [PubMed]

57. Kahl, T.; Arnstadt, T.; Baber, K.; Bässler, C.; Bauhus, J.; Borken, W.; Martin, M.G. Wood decay rates of 13 temperate tree species in relation to wood properties, enzyme activities and organismic diversities. For. Ecol. Manag. 2017, 391, 86-95. [CrossRef]

58. Kahl, T.; Baber, K.; Otto, P.; Wirth, C.; Bauhus, J. Drivers of $\mathrm{CO}_{2}$ emission rates from dead wood logs of 13 tree species in the initial decomposition phase. Forests 2015, 6, 2484-2504. [CrossRef]

59. Blanco, J.A.; Page-Dumroese, D.S.; Jurgensen, M.F.; Curran, M.P.; Tirocke, J.M.; Walitalo, J. Modelling the management of forest ecosystems: Importance of wood decomposition. Nat. Resour. Modell. 2018, 31, e12173. [CrossRef]

(C) 2020 by the authors. Licensee MDPI, Basel, Switzerland. This article is an open access article distributed under the terms and conditions of the Creative Commons Attribution (CC BY) license (http://creativecommons.org/licenses/by/4.0/). 